\title{
Delegation and Regulatory Reform: Letting the President Change the Rules
}

\author{
A widespread attack on the federal regulatory system ${ }^{1}$ has recently
} generated numerous proposals for substantive, ${ }^{2}$ procedural, ${ }^{3}$ and struc-

tural reform. ${ }^{4}$ The proposed structural reforms would shift authority to the courts, ${ }^{5}$ to Congress, ${ }^{6}$ or to the President ${ }^{7}$ and therefore present the most direct attempt to redistribute political power. Last summer the American Bar Association urged enactment of one of the most far-reaching structural reforms, a proposal called Resolution A. ${ }^{8}$ If

1. See, e.g., Senate Comm. on Government Operations, 951h Cong., Ist Sess., Study on Federal Regulation (1977) (six volume study) [hereinafter cited as Study on Federal. REgulation].

The regulatory system is criticized not only for problems that are unique to itself, but also for problems that it shares with big government or large organizations generally. Some critics believe, moreover, that regulatory problems have their roots deep within the American political economy. See, e.g., Noll, The Economics and Politics of Regulation, 57 VA. L. REv. 1016, 1027-31 (1971).

2. E.g., Airline Deregulation Act of 1978, Pub. L. No. 95-504, 92 Stat. 1705 (1978) (lowering entry and exit barriers; encouraging competition). See generally Breyer, Analyzing Regulatory Failure: Mismatches, Less Restrictive Alternatives, and Reform, 92 Harv. L. Rev. 549 (1979) (proposing criteria for different types of substantive reform).

3. E.g., S. 262, 96th Cong., 1st Sess., 125 Conc. Rec. S861 (daily ed. Jan. 31, 1979) (requiring agencies to prepare analyses of regulatory impact); Lazarus \& Onek, The Regulators and the People, 57 VA. L. REv. 1069, 1094-1108 (1971) (advocating wider participation rights).

4. See Thomas, Politics, Structure, and Personnel in Administrative Regulation, 57 VA. L. REv. 1033, 1035-43 (1971) (reviewing history of structural reform).

5. E.g., S. 1477, 96th Cong., lst Sess., 125 CoNc. Rec. S12,145 (daily ed. Sept. 7, 1979) (amending Administrative Procedure Act $\$ 10(e), 5$ U.S.C. $\$ 706$ (Supp. I 1977), to require de novo review of all legal questions and to remove presumption that regulation is valid); see McGowan, Congress, Court, and Control of Delegated Power, 77 Colum. L. Rev. 1119, $1162-68$ (1977) (discussing earlier version of S. 1477).

6. The major proposal that would shift authority to Congress is the legislative veto, discussed in notes 42, 52, 58, \& 66 infra; McGowan, supra note 5, at 1133-62. One such proposal with substantial support would subject all agency rules to a "one-and-a-half house veto"-i.e., one house could veto if the other did not reject that veto within a fixed time period. H.R. 1776, 96th Cong., 1st Sess. (1979).

7. See President's Advisory Council on Executive Organization, A New RegulaTORY FRAMEWORK 20-26 (1971) (advocating consolidation of several independent agencies, with single administrator responsible to President) [hereinafter cited as AsH CounciL Report; President's Comm. on Administrative Management, Report of the Committee with Studies of Administrative Management in the Federal Government 41-42 (1937) (proposing independent agencies be made responsible to and removable by the President).

8. American Bar Ass'n, Summary of action of the House of Delegates 11-12 (Aug. 1979); see 65 A.B.A.J. 1284 (1979) (discussing debate over Resolution A). Resolution A grew out of a proposal advanced by Lloyd N. Cutler and David R. Johnson in Regulation and the Political Process, 84 YALE L.J. 1395 (1975). That proposal has generated an ongoing debate. See, e.g., Subcomm. on Oversight and INvestigations, House Comm. ON Interstate and Foreign Commerce, 94Th Cong., 2d Sess., Federal Regulation and ReguLAtory Reform 532-34 (Subcomm. Print 1976) [hereinafter cited as Federal Regulation 
enacted, Resolution A would authorize the President to control the content of regulations in order to promote balance and accountability in the regulatory system. ${ }^{9}$

This Note argues that balance, accountability, and regulatory effectiveness are inconsistent goals for a system in which specialized agencies exercise delegated power; in order to achieve its ends, Congress must delegate a further power to resolve conflicts among those agencies. Structural reform is therefore analyzed as a problem in delegation: who should be granted authority to impose compromises among regulatory goals? This Note contends that delegating that power to the President, as proposed in Resolution A, is politically unrealistic, poorly tailored to the aims of reform, and destructive of the safeguards that traditionally serve to constrain delegations. It concludes by offering an alternative proposal that would meet the needs of reform without endangering important political and constitutional values.

\section{The Politics of Reform}

Effective reform must proceed from an understanding of the political forces that have shaped and continue to shape the regulatory system. Resolution A, by contrast, rests upon the unrealistic hope that Congress will voluntarily relinquish highly valued regulatory powers to the President.

\section{A. The Present System in Political Perspective}

The federal regulatory system, consisting of both independent and executive-branch agencies, is the problematic answer to a congressional dilemma: how to use powers that Congress is unable to exercise directly, but unwilling to delegate to the President. Congress maintains a "special relationship" 10 with independent agencies and jealously guards

AND Regulatory Reform]; Byse, Comments on a Structural Reform Proposal: Presidential Directives to Independent Agencies, 29 AD. L. REv. 157 (1977); McGowan, supra note 5, at 1168-73. An ABA commission recommended a modified version of the Cutler-Johnson proposal in an "exposure draft report," AMERICAN BAR Ass'N CoMm'N ON LAw AND THE Economy, Federal Regulation: Roads to Reform 93-114 (1978) [hereinafter cited as RoADs to REFORM], and part of that report was revised and submitted to the ABA House of Delegates at its annual meeting, American Bar Ass'n Comm'n on Law and the Economy, Report to the House of Delegates (Report No. 121, Aug. 1979) (on file with Yale Law Journal) [hereinafter cited as Report No. 121].

9. See note 27 infra (reprinting Resolution A).

10. Federal Regulation and Regulatory Reform, supra note 8, at 426 (special relationship arises from Congress's constitutional power to limit presidential intervention). 
the authority it delegates to executive-branch agencies. ${ }^{11}$ It shields independent commissioners from presidential interference by attaching qualifications and a fixed term to their offices and by narrowly specifying the grounds for their removal. ${ }^{12}$ It tries both to control and to shield executive-branch agencies by vesting discretionary authority in an administrator and then defining the standard or the factors to be weighed in his decisions. ${ }^{13}$ Congress attempts to exert ongoing control through new legislation, periodic authorization or appropriation, oversight, and the exercise of legislative vetoes. ${ }^{14}$ Augmenting these controls is a pervasive network of informal contacts..$^{15}$

The President is not without weapons in this political tug of war. Wielding the executive power, he directs and coordinates executive agencies, and staffs them with loyal supporters. ${ }^{16} \mathrm{He}$ names the chair-

11. See id. at 439 .

12. See Humphrey's Ex'r v. United States, 295 U.S. 602, 625 (1935) (stressing independence from President).

13. See, e.g., Pacific Legal Foundation v. Department of Transp., 593 F.2d 1338, 134344 (D.C. Cir. 1979) (reviewing administrator's role under Motor Vehicle Safety Act); cf. FTC v. Ruberoid Co., 343 U.S. 470, $487-90$ (1952) (Jackson, J., dissenting) (discussing connection between agency independence and ability to weigh congressional concerns). Courts have invalidated decisions that take into account factors not specified in the legislation. E.g., D.C. Fed'n of Civic Ass'ns v. Volpe, 459 F.2d 1231, 1246 (D.C. Cir. 1971), cert. denied, 405 U.S. 1030 (1972) (decision invalid because of pressure by congressman).

President Carter has recently attempted to test his authority to intervene in discretionary judgments that Congress has vested in other executive-branch officers. See Report No. 121, supra note 8 , at 13-16 (discussing presidential intervention into cotton dust, strip mining, and ozone regulations). Whether the President may direct the exercise of discretion expressly vested in an executive-branch officer is questionable. See Bruff, Presidential Power and Administrative Rulemaking, 88 YALE L.J. 451, 495-98 (1979) (proposing framework for analyzing various interventions). Though a majority of the ABA Commission on Law and the Economy believes that the President possesses such power, see Report No. 121, supra note 8, at 20, the leading cases on presidential removal power recognize a class of quasi-legislative and quasi-judicial functions-within or outside of the executive branch-that the President may be powerless to control. See Humphrey's Ex'r v. United States, 295 U.S. 602, 627-29 (1935) (Congress may limit President's power to remove officers not "purely executive" in function); Myers v. United States, 272 U.S. 52, 135 (1926) ("[T]here may be duties so peculiarly and specifically committed to the discretion of a particular officer as to raise a question whether the President may overrule or revise the officer's interpretation of his statutory duty ..."); cf. United States v. Nixon, 418 U.S. 683, 694-96 (1974) (Congress vested prosecutorial power in Attorney General, whose regulations remain binding on President).

14. See note 6 supra; Federal Regulation and Regulatory ReForm, supra note 8, at 439, 519-21 (summarizing congressional tools for agency control).

15. Political scientists have observed a powerful and symbiotic "triangular relationship" among the congressional committee, the agency, and the agency constituencyusually, the regulated industry. All three are reluctant to disrupt lines of communication. See T. Cronin, The State of the Presidency 93.96 (1975).

16. See Myers v. United States, 272 U.S. 52 (1926) (upholding presidential power to remove executive officers). The Court rested the Myers decision in part upon the President's need to coordinate the execution of the laws. Id. at 135. See generally Bruff, supra note 13 , at 463.65 (analyzing presidential authority to coordinate). 
men and many commissioners of the independent agencies. ${ }^{17} \mathrm{He}$ has general control over government budgeting and litigation, ${ }^{18}$ and limited statutory authority for impoundment, reorganization, and regulatory intervention. ${ }^{19}$ Finally, he wields the veto and immense informal influence..$^{20}$

Regardless of their merit, structural regulatory reforms that favor either branch will encounter resistance from political interests tied to the present system. Congress has recently reversed the expansion of the President's power ${ }^{21}$ and will surely resist giving him new authority to intervene in agency rulemaking. ${ }^{22}$ At the same time, the President opposes sweeping legislative veto proposals because they would erode his authority and facilitate special-interest interference with coordinated regulatory policy. ${ }^{23}$ Yet strong pressures impel some kind of change: critics attribute much of the nation's inflation and declining productivity to bureaucracy and regulation, and business is anxious to reduce the burdens on itself. ${ }^{24}$ Lacking an electoral base, regulators have become convenient targets. ${ }^{25}$ Reform must therefore avoid, on the one hand, a stalemate between unrealistic presidential and congressional proposals and, on the other, a compromise aimed at political acceptability rather than at regulatory needs. ${ }^{26}$

17. See Robinson, On Reorganizing the Independent Regulatory Agencies, 57 VA. L. REv. 947, 951 \& n.14 (1971) (within short period, President appoints majority of commissioners). Commission chairmen have considerable control over administration and staffing, and hence over the direction of policy. Lazarus \& Onek, supra note 3, at 1085.

18. See Lazarus \& Onek, supra note 3, at 1085-87 (Office of Management and Budget controls budget proposals; Justice Department has discretion to enforce agency subpoenas). Even more important, perhaps, is the Solicitor General's control over appellate litigation.

19. See Bruff, supra note 13, at 491-95.

20. See Robinson, The Federal Communications Commission: An Essay on Regulatory Watchdogs, 64 VA. L. REv. 169, 206-12 (1978) (President's personal contact and moral suasion influences independent-agency policy).

21. See Leidenstein, The Reassertion of Congressional Power: New Curbs on the President, 93 Polrtical Scr. Q. 393 (1978) (discussing limitations in several areas including spending, foreign policy, reorganization).

22. See Bruff, supra note 13, at 452; Robinson, supra note 17, at 949.

23. See McGowan, supra note 5, at 1132-45.

24. See, e.g., RoAds to ReForM, supra note 8, at 8; Kennedy, Regulatory Reform: $A$ Confused National Issue, 28 AD. L. REV. 447, 447-49 (1976).

25. The political vulnerability of agencies is not new. See Wiltse, The Representative Function of Bureaucracy, 35 AM. Political Sar. Rvv. 510, 514-15 (1941) (agencies spare Congress burden of disappointing powerful interests and then assume role of scapegoat in congressional speeches).

26. The original Cutler-Johnson proposal combined the presidential powers of Resolution A with a congressional veto. Cutler \& Johnson, supra note 8, at $1415-16$. The veto provision was thought to be constitutionally questionable, but necessary to secure adoption. Id. The ABA proposal dropped the veto because of its possible unconstitutionality. RoADs to REFORM, supra note 8, at 110-14. A bill similar to the original Cutler-Johnson compromise, i.e., with a veto provision, has been introduced by Sen. William V. Roth of Delaware. S. 1545, 96th Cong., 1st Sess., 125 ConG. REc. S9898 (daily ed. July 19, 1979). 


\section{B. An Outline of Resolution A}

Resolution $A^{27}$ would effect a massive shift of power from Congress to the President. The President's new authority would encompass, with few exceptions, control over the rules and regulations of all independent and executive-branch agencies. ${ }^{28}$ By granting him the power to initiate, modify, or veto critical regulations, Resolution A would permit the President to exercise the full rulemaking power of almost every agency. ${ }^{20}$

The President could invoke his new authority after making a formal finding that the matter in question involved a "critical regulation"that is, a regulation of major significance to the national interest, affecting one or more competing statutory goals..$^{30} \mathrm{He}$ would then, by

\section{Resolution A reads:}

BE IT RESOLVED, That the American Bar Association supports enactment of a statute authorizing the President to direct certain regulatory agencies, within and outside the executive branch, to consider or reconsider the issuance of critical regulations, within a specified period of time, and thereafter to direct such agencies to modify or reverse their decisions concerning such regulations. "Critical" regulations should be defined as those the President finds to be of major significance both to the national interest and to the achievement of one or more statutory goals in addition to the goal primarily entrusted to the regulatory agency in question. Such a statute (1) should contain adequate subject matter limitations and procedural safeguards governing presidential exercises of this authority; (2) should not authorize intervention in licensing and ratemaking cases and should confine the President to the appropriate exercise of the agency's statutory discretion upon the basic facts (as distinguished from the ultimate conclusions) determined by the agency; (3) should provide time for congressional reaction before presidential orders become effective; (4) should expire after a limited time, so that Congress could refuse to extend the authority if the President did not adequately take congressional reaction into account; and (5) should not change the standards applicable to agency actions upon judicial review.

AMERICAN BAR Ass'n, supra note 8, at 12.

28. See Report No. 121, supra note 8, at 22. Resolution A covers rulemaking and regulations of general application; it excludes adjudication, licensing, and ratemaking. $I d$. at 25. It also would exempt the money market functions of the Federal Reserve Board, the campaign-financing functions of the Federal Election Commission, and certain noneconomic regulatory issues such as broadcast fairness. Id. at 25-26. The Report urges that any other exemptions be kept to a minimum. Id. at 27. The ABA Commission on Law and the Economy had earlier favored inclusion of ratemaking and of licensing under certain circumstances. ROADS To REFORM, supra note 8, at 103-04. In its later Report, the Commission limited the scope of Resolution A, with the option of expanding it after the experience could be evaluated. Report No. 121, supra note 8, at $25 \mathrm{n} .30$. The scope of the President's proposed power, even with these limits, is emphasized by the Commission's observation that "it is difficult to find any economic activity that is not now subject, in some form, to regulatory mandates or restraints." ROADS To REFORM, supra note 8, at 8 .

29. See Report No. 121, supra note 8, at 22. The Report refers to "regulations" rather than rulemaking, presumably to include actions that fall outside the categories of formal or informal rulemaking, and to exclude ratemaking. Id. at 25. Resolution A would permit the President to take any action within the statutory power, id. at 22-23, and discretion, id. at 25 , of the agency in question; his action would have to be based, moreover, only on the basic facts-not on the ultimate conclusions-found by the agency. Id.

30. The President's findings would be published in the Federal Register, along with the reasons for his action. Id. at 23. The required findings would place little restriction 
Executive Order, direct the appropriate agency to consider issuing a particular regulation or to reconsider a regulation already issued. ${ }^{31}$ The agency would undertake its normal rulemaking procedure, observing its regular practices and safeguards ${ }^{32}$-and thus ostensibly preserving the basic fairness of the administrative process. ${ }^{33}$ After the agency had completed that process, the President could direct it to reconsider, reverse, or modify its decision. ${ }^{34}$

The most important effect of Resolution $A$ would be the leverage given the President in all his dealings with the agencies and Congress. The President would have an unprecedented capability-exercised, threatened, or tacit-to interfere with the special relationship between the agencies and Congress. ${ }^{35}$ That power would be felt well before it

upon presidential actions, for no court would challenge a president's assertion that an action was of major significance to the national interest. The interdependence of goals is, moreover, a principal premise of Resolution A: "[All social goals] are systematically related; some require each other; some exclude each other; nearly all compete with each other for limited resources. ..." Cutler \& Johnson, supra note 8, at 1405 n.33 (quoting G. ViGKeRs, FreEDoM IN A Rocking BoAT 125 (1970)).

31. Executive Orders could not be issued until 30 days after publication to allow for written comments. Report No. 121, supra note 8, at 22-23.

32. The President and his staff would be bound by the agency's rules regarding ex parte contacts and decisionmaking on the public record. After the Executive Order took effect, the agency would issue its own notice of proposed rulemaking. Memoranda between the White House and the agency would be made part of the public record; the fact of oral communication would be noted, but its substance would remain private. Report No. 121, supra note 8 , at 24 .

33. The adequacy of those procedures has been challenged by several dissenting ABA Commission members. See, e.g., Separate Statement of William T. Coleman, Jr., reprinted in id., app. [hereinafter cited as Coleman Dissent]; Separate Statement of Rhoda $H$. Karpatkin, reprinted in id., app. [hereinafter cited as Karpatkin Dissent]. Those statements noted that, after losing at an open hearing, persons with special access to the White House would have a second chance-and might unfairly benefit from ex parte contacts, from behind-the-scenes influence by anonymous, uninformed, and unaccountable White House personnel, and from an unreviewable presidential decision. See Coleman Dissent, supra, at 3-6; Karpatkin Dissent, supra, at 1-2.

34. Two restrictions attempt to mitigate the shift of power from Congress to the President. One provides Congress with an opportunity to comment on the presidential order by requiring that a specified time period elapse before the order takes effect. During that time, the President would retain discretion to modify or withdraw the order in light of Congress's comments. See Report No. 121, supra note 8, at 24. Congress's negotiating position would, however, reflect the fact that it could not reverse the President except through legislation subject to his veto.

The second restriction is a sunset provision that emphasizes the experimental nature of the reform. Id. at 24-25. A prudent President would exercise his authority sparingly at first-the Commission estimates no more than three to four times per year. Id. at 27. As Congress grew accustomed to his use of the power, and as the threat of its nonrenewal diminished, a slow shift of power would likely occur despite the sunset provision. Any attempt to remove the power before its expiration would meet a possible presidential veto.

35. For example, in the face of congressional recalcitrance to enact his energy program, a President would be in a position to alter regulations dealing with auto exhaust and power plant emissions, air quality standards, oil imports and price levels, auto safety 
was used: because both Congress and the agencies would know that the President had ultimate authority to control agency decisions, neither would be as likely to stray from his expectations. It is realistic to assume, moreover, that the President would use his power for the widest range of purposes. ${ }^{36}$ Resolution $A$ would thus introduce a major new weapon into the presidential arsenal.

\section{Defining Regulatory Needs: A Structural Analysis}

In theory, the regulatory system must meet three legislative needs. First, a heavy legislative burden forces Congress to delegate some of its decisionmaking tasks to agencies that can devote full time and apply special competence to specific areas; ${ }^{37}$ the narrower the delegations, the more efficiently and faithfully can the agencies carry out Congress's will. ${ }^{38}$ Second, if the delegation is to lift the burden from Congress,

equipment, utility fuel selection, tariffs, product safety and information, oil and gas pipelines, vehicle weight and fuel consumption, nuclear plant safety, waste disposal and fuel export, offshore leasing, mine safety, and many other subjects. See RoAds to REForM, supra note 8, at 97-99 (listing agencies that affect price and supply of energy). Because many congressmen who oversee the affected agencies might prefer to give the President his program in order to protect regulators from his interference, the President might never need to use his formal authority.

36. See Coleman Dissent, supra note 33, at 5 (arguing that "it is inconceivable that such a process ... would not be utilized frequently.").

37. The term "special competence" refers throughout this Note to the combination of bounded legal authority and the narrowed-sometimes expert-perspective of regulators. Because legislators are necessarily generalists, they cannot possibly attend to all the details of the policies they enact. It has thus long been recognized that someone other than the legislature would have to make regulations to "fill up the details." United States v. Grimaud, 220 U.S. 506, 517 (1911) (quoting Wayman v. Southard, 23 U.S. (10 Wheat.) 1, 43 (1825) (opinion of Marshall, C.J.)). This power was originally thought to be administrative, not legislative. Id. As the legislative job grew, wider discretion had to be delegated to administrators. The emphasis began to shift, therefore, to the expertise developed by those who devote their full time to administering a particular law. See Hampton \& Co. v. United States, 276 U.S. 394, $404-09$ (1928) (legislative power may not be delegated, but determining production costs for tariff is administrative task). The Court eventually dropped the fiction that Congress was delegating only powers of execution and began referring to powers that were "quasi-legislative," Humphrey's Ex'r v. United States, 295 U.S. 602, 628 (1935), but confined within congressionally defined and judicially enforced bounds. Though the agencies' expertise may be open to question, Congress's need to delegate is undeniable. See Federal Regulation and Regulatory Reform, supra note 8, at 526 (expert agencies needed to avoid "swamping" Congress).

38. Contrary to the theoretical ideal, many agencies are given broad discretion, albeit within a single industry, under a public-interest standard. See Stewart, The Reformation of American Administrative Law, 88 HARv. L. REv. 1667, 1676-77 (1975). Such breadth is rationalized in terms of flexibility, id. at 1679 , or interest balancing, id. at $1683-84$, but it clearly conflicts with traditional notions of a proper delegation under legislative control, see id. Broad delegation reflects an inability to reconcile tensions among the regulatory requirements of narrowness, administrative flexibility, and balance. See pp. 568.69 infra. This Note argues that such tensions are inherent in the nature of delegation. 
an agency must be able to exercise decisive, ${ }^{39}$ binding authority within its area of competence without constant legislative supervision. ${ }^{40} \mathrm{Third}$, an agency cannot be faithful to its legislative mandate if it suffers interference or reversal by factional interests-that is, its choices must be independent of anything less than a reassertion of the legislative will.41

The qualities of special competence, decisive authority, and independent choice are essential features of an ideal regulatory structure. Each of these features gives rise to a structural problem that Resolution $A$ is designed to solve. ${ }^{42}$

\section{A. Balance Among Specialists}

Special competence-the result of an agency's focused perspective and circumscribed authority-can create a problem of balance. A complex society is regulated pursuant to many competing and sometimes conflicting goals. ${ }^{43}$ Yet single-mission agencies lack the vision, ${ }^{44}$ the incentive, ${ }^{45}$ and often the authority ${ }^{46}$ to weigh other goals against their

39. The term "decisiveness" is used in this Note to refer to an agency's ability to issue regulations without running the legislative gauntlet.

40. Legislation is sluggish and cumbersome, and a high degree of consensus is necessary to change the status quo. See 2 Study on Federal Regulation, supra note 1, at 116. Regulation, on the other hand, was designed to combat monopoly or other market failure, where the presumptive legitimacy of the status quo and nonintervention is weaker. See Breyer, supra note 2, at 553-60. It can therefore be argued that fewer obstacles should stand in the way of changing a regulation than of changing a statute.

41. "Independence," as the term is used in this Note, is an attribute of executivebranch as well as of independent agencies and refers to authority vested expressly in an agency or administrator, and not subject to the direction of a superior officer. See note 13 supra. Whether or not Congress may bar presidential control of executive-branch rulemaking, the President intervenes, as a practical matter, only infrequently. See Bruff, supra note 13 , at 465 .

42. An alternative solution to the problems addressed by Resolution $\mathrm{A}$ is the legislative veto, a mechanism by which a part of Congress-such as a single house-can block or rescind agency rules. See note 6 supra. Like Resolution $A$, the legislative veto involves a delegation of legislative authority to a body that comprises only one of several necessary actors in the legislative process; many of the drawbacks of Resolution $A$ are thus shared by the legislative veto. See notes 52,58 , and 66 infra.

43. Report No. 121, supra note 8, at 4-7; see Brufl, supra note 13, at 454-56; Cutler \& Johnson, supra note 8, at 1406-07.

44. See Ash Council Report, supra note 7, at 41; M. Bernstein, Regulating Business BY INDEPENDENT CoMMission 146-47, 155-62 (1955).

45. Even if agencies were required to weigh competing goals, it is doubtful that they would do so objectively. For instance, after reviewing various mechanisms to induce agencies to weigh goals other than their primary mandated objectives, the ABA Commission on Law and the Economy noted that "no agency has yet filed [an Inflation Impact Statement] concluding that the benefits of the action it was considering were outweighed by the costs." Report No. 121, supra note 8 , at 32 .

46. The Environmental Protection Agency (EPA), for example, maintains that the Clean Air Act, 42 U.S.C. $\$ \$ 7401-7626$ (Supp. I 1977), does not permit it to consider cost in setting National Ambient Air Quality Standards, id. \$ 7407. See 44 Fed. Reg. 8202, 8203 (1979) (ozone standard). The Supreme Court has reached a similar conclusion with respect to the acceptance of state air quality plans. See Union Electric Co. v. EPA, 427 U.S. 246, 256 (1976). 
mandated objectives. ${ }^{47} \mathrm{~A}$ broader mandate might permit an agency to implement a more comprehensive balance, ${ }^{48}$ but so long as the scope of the delegation is limited, some goals will remain outside the agency's special competence. Moreover, a broad mandate would destroy the efficiency of specialization and make an agency more difficult to control.49

In theory, Congress performs the requisite balancing through its mandates to the agencies; ${ }^{50}$ in practice, it seldom sets priorities among regulatory goals. Instead, Congress relies on committees whose narrow outlooks often parallel those of the agencies themselves. ${ }^{51}$ Even if its legislative process were not specialized or decentralized, however, Congress could not anticipate all future regulatory conflicts or changes in priorities; balance would require continual readjustment. Yet the system lacks a regular process for discovering and modifying regulations that, though statutorily proper, exact too high a price in terms of other goals. The central concern of Resolution $A$ is to make possible such a process. $^{52}$

\section{B. Limits Upon Authority}

When an agency exercises authority within its area of special competence, it affects goals outside of that area and thus extends its power

47. See p. 567 supra.

48. See Robinson, supra note 17 , at 985 (reviewing recommendations that agency mandates be broadened to correct imbalance).

49. See pp. 575-76 infra.

50. The Court described the congressional balancing process in the snail darter case, TVA v. Hill, 437 U.S. 153, 18I-85 (1978). In that case, a statute had required agencies to protect endangered species whenever protection was "consistent with the[ir] primary purposes." Id, at 181. The Court interpreted subsequent congressional deletion of that qualifying language as giving the new statutory goals priority over the agencies' primary missions. Congress undertook a similar balancing process when it authorized the Federal Energy Administration to require utilities to burn coal, but directed that agency to consult with, and ultimately to defer to, the EPA on permissible power plant emission levels. See Energy Supply and Environmental Coordination Act of 1974, § 2(b), I5 U.S.C. § 792(b) (1976); RosDs to ReForar, supra note 8, at 98.

51. See H. Friendly, The federal Administrative Agencies 169-71 (1962); Robinson, supra note 17 , at 955.

52. Report No. 121, supra note 8, at 4. Proponents of Resolution A believe that balancing judgments must be made by a generalist such as the President. But the President's staff would probably make most of the preliminary decisions, and outcomes would thus depend upon the relative power and access of various staff specialists. Likewise, the rival legislative veto proposals seek to locate balancing decisions in the nonspecialized arena of a congressional chamber. But the burden of reviewing agency rules would require Congress to divide the work among its committees, and balancing would again be carried out by specialists. The experience with existing legislative vetoes displays precisely this pattern. See Bruff \& Gellhorn, Congressional Control of Administrative Regulation: $A$ Study of Legislative Vetoes, 90 HARv. L. REv. 1369, 1417-20 (1977). 
beyond its intended bounds. ${ }^{53}$ Those bounds might be widened or removed to avoid such a problem, but that solution would increase the agency's power, dull its focus, and hinder legislative or judicial control. ${ }^{54}$ Agencies might be denied authority to act without legislative approval, but that would defeat the purpose of delegation by making Congress duplicate the agency's work. ${ }^{55}$ Congress can perfect its control over decisive agencies, therefore, only if it ensures that balancing decisions will be made and will be imposed upon the agencies whenever their decisions conflict.

Congress holds the authority, of course, to displace any regulation with a legislative compromise that better reflects its goals. ${ }^{56}$ But the degree of consensus required to pass such legislation is greater than that needed to block it. Absent a large majority favoring the compromise, the attempt to impose a balance will fail, and the agency will exercise decisive authority with respect to goals outside its area of special competence. ${ }^{57}$ Thus a balance among goals can be imposed with decisiveness equal to that of the agency if, but only if, Congress delegates superseding authority to another body. Resolution A would delegate such authority to the President. ${ }^{58}$

53. For example, though the EPA is not permitted to consider cost or energy consumption in setting National Ambient Air Quality Standards, see note 46 supra, its decisions will inevitably influence both inflation and energy use.

54. See p. 567 supra; pp. 575-77 infra.

55. See p. 568 supra.

56. For example, the Department of Transportation's rule requiring seatbelt-ignition interlock systems, 37 Fed. Reg. 3911 (1972), was overturned when Congress banned interlocks and continuous buzzers. Motor Vehicle and Schoolbus Safety Amendments of 1974, $\S 109$ (b), 15 U.S.C. $\$ 1410$ (b) (1976). See Cutler \& Johnson, supra note 8, at 1400 (discussing this congressional intervention).

57. See Cutler \& Johnson, supra note 8, at 1401 (describing Congress's inertia).

58. Report No. 121, supra note 8 , at 22.

Like Resolution $A$, the legislative veto also strives for decisiveness. It would delegate balancing authority to a part of Congress, rather than to the President. See 2 STudy oN Federal Regulation, supra note 1 , at 115-17. For the same reason, even congressional committees are occasionally delegated authority to veto or to approve agency actions. See id. at 203-72 (study of committee authority). One-house vetoes do not, however, fall within the few categories of binding, single-chamber action specified in the Constitution. E.g., U.S. Consr. art. I, $\S 2$, para. 5 (impeachment); id. $\$ 5$ (various internal rules and qualifications). Congress may delegate authority to one of its own committees if the committee functions as a necessary adjunct to the exercise of legislative power, for example, in gathering information through subpoena. See Buckley v. Valeo, 424 U.S. 1, 137-38 (1976) (discussing types of action that may be taken by a nonofficer of the United States). But rule-vetoing, like rulemaking, is arguably a quasi-legislative function that can be exercised only by an officer of the United States. See id. at 140-41 (nonofficer may not exercise rulemaking or other "significant governmental" authority). If the legislative veto is a delegation of significant authority, therefore, it is unconstitutional because those exercising it are not duly appointed officers of the United States, U.S. CoNST. art. II, $\S 2$, para. 2, and because members of Congress are prohibited from holding office during their tenure, id. art. $I, \S 6$, para. 2 .

Whether or not it is constitutional, the legislative veto will be treated as a delegation 


\section{Independence With Accountability}

The power to make independent choices permits an agency, within its mandate, not only to act on its own initiative, but also to resist being directly checked by those who disagree with its decisions. Because agencies may resist the will of majorities as well as minorities, independence poses a problem of accountability. ${ }^{59}$ Once a statutory mandate exists, agency decisions require only enough support to withstand legislative reversal, not to achieve affirmative legislative victory. Freed from the interference of all but large majorities, an agency can undertake ongoing regulation through a process of low-consensus-and hence relatively unaccountable-decisionmaking. ${ }^{\circ 0}$

A prevailing coalition can either favor or burden an affected party more readily through an agency's low-consensus decisionmaking than through ongoing legislative action. ${ }^{11}$ Depending upon the composition of that coalition, an agency can fail, in the eyes of critics, either because it has been "captured" by the industries it regulates, or because it is overly zealous. ${ }^{62}$ Agency capture is not solely a regulatory problem; in-

for purposes of solving the structural problem of authority: that is, Congress must delegate to another body the decisive power to impose balances, and that other body might be a part of Congress. See Stewart, supra note 38, at $1695 \mathrm{n} .128$ (describing congressional authority short of legislation as "effective delegation").

59. The failure of regulatory accountability is a common complaint. It is defined as an instance in which "an agency has not done what elected officials would have done." Cutler \& Johnson, supra note 8, at 1399; see 2 Study on Federal Regulation, supra note 1, at 5; Federal Regulation and Regulatory ReForM, supra note 8, at 2-3. The criticism must be carefully evaluated, however, since one cannot know what elected officials-or at least a legislative majority-would have done. Because regulators are necessarily appointed, anyone who disagrees with a particular regulation can credibly complain that it was the result of regulatory failure.

Unaccountability might also characterize agency actions that diverge from societal values. If a statutory mandate reflected those values but granted an agency wide discretion, the administrator could depart drastically from the point of maximum social preference, and a court would lack the guidance to improve upon his choice. Often, however, a statutory mandate that permits only narrow discretion may be the product of an unrepresentative and unaccountable congressional committee. See p. 569 supra; p. 572 infra. Finally, even the narrowest statute drafted by the most representative and responsible committee would be unable to assure socially preferred regulations in the face of changing priorities and unanticipated regulatory conflicts.

60. See Cutler \& Johnson, supra note 8, at 1401; Ribicoff, Congressional Oversight and Regulatory Reform, 28 AD. L. REv. 415, 420 (1976). Low-consensus decisions are inherent in delegation, irrespective of the American system's peculiar inertia. So long as action requires greater consensus than does inaction, a delegate's authority will be more difficult to recall than to tolerate.

61. See Lazarus \& Onek, supra note 3, at 1093-94 (public opinion sufficient to cause legislative enactment is insufficient to control administration); Schwartz, Crisis in the Commissions, The Progressive, Aug. 1959, at 10-13 (describing how legislation intended to control monopoly was used to promote it).

62. The capacity to swing from one extreme to the other is illustrated by the Federal Trade Commission. Described in 1975 as captured by industry and unresponsive to con- 
terest-group influence is endemic to representative democracy. ${ }^{.3}$ But single-interest agencies, as well as their oversight committees, may be more easily captured to the extent that they lack the check provided by the normal interplay among competing groups. ${ }^{04}$ Similarly, an absence of balance among competing goals may underlie the charge of excessive zeal: narrow agencies or narrow committees possess neither the incentive nor the special competence to evaluate some factors that would suggest restraint. ${ }^{65}$

Unaccountability is thus an inherent danger when Congress delegates independent authority to specialized agencies. Congress could reduce that independence by establishing a veto process requiring something less than legislation, but such a process would not assure accountability to the public: no single actor speaks with authority as to societal values. ${ }^{66}$ Congress might make regulators directly accountable by providing for their popular election, but that would require a constitutional amendment. ${ }^{67}$ If a nonspecialized committee of congressional leaders proposed balanced legislative solutions to regulatory conflicts and pushed them through the legislative gauntlet, those compromises could reasonably claim to represent societal values. But no

sumers, see Freedman, Crisis and Legitimacy in the Administrative Process, 27 STAN. I. REv. 1041, 1074 (1975), that agency is now criticized for excessive zeal, see, e.g., 37 CoNG. Q. WEEKLY REP. 1648 (1979) (corporate executive calls FTG chairman "socialist . . . committed to the dissection of large corporations").

63. The general problem is whether a large but unorganized or apathetic majority can (or should) prevail over an intense and interested minority. For discussion of this problem in various contexts, see R. NoLL, REForming REgulation 41 (1971) (regulatory system); Posner, The Federal Trade Commission, 37 U. CHI. L. Rev. 47, 82-83 (1969) (Congress); R. Dahl, A Preface to Democratic Theory 90-119 (1956) (political system as a whole).

64. See Moss v. CAB, 430 F.2d 891, 893 (D.C. Cir. 1970) (ex parte ratemaking procedure invalid; facilitates agency capture by fencing out public); Stewart, supra note 38, at 1713-15 (diagnosing imbalance in group representation before agencies).

65. See, e.g., Commoner, Law from the Perspective of Ecology, in Administrative Law 45 (B. Schwartz ed. 1977) (excessive environmental regulation and bureaucratization).

66. Both Resolution $A$ and the legislative veto proposals imply that disagreement with an agency decision by the President or one house of Congress indicates a failure of regulatory accountability. Yet neither the President nor a house of Congress alone can operate the constitutionally established machinery for determining policy. An agency's process has at least been passed and signed according to law and is reviewable in the courts. Both the President and a single congressional chamber suffer, moreover, from their own problems of partiality and accountability; it is the balance among the President and two houses that the Constitution trusts to reflect society's values. See W. GellhorN \& C. Byse, Administrative Law 122.27 (6th ed. 1974) (citing sources on problem of congressional action short of legislation); FEDERAL Regulation and Regulatory Reforar, supra note 8 , at 533 (criticizing executive branch as influenced by factions and lacking balance).

67. Since regulators are officers of the United States, the method of their selection is expressly provided for in Article II, $\$ 2$ of the Constitution. See Buckley v. Valeo, 424 U.S. 1, 140-41 (1976) (denying quasi-legislative authority to commissioners not appointed by the President); Stewart, supra note 38 , at $1791 \mathrm{n} .559$ (electing regulators would require amendment). 
such committee exists. Thus few such legislative solutions are enacted, and unaccountability remains embedded in the regulatory structure.

These three problems of delegation-achieving balance in spite of specialization, restraint in spite of decisiveness, and accountability in spite of independence-define the needs of structural regulatory reform, and those needs reduce to a single idea: devising a mechanism for reaching and enforcing socially preferred balances among competing regulatory goals. By vesting balancing authority in a nationally elected official, Resolution A purports to eliminate three structural problems at one stroke. ${ }^{68}$

\section{The Dangers of Overbroad Delegation}

Structural reform must be carefully tailored to the needs of the existing system. A tight-fitting proposal is better able to meet its regulatory objectives ${ }^{60}$ and more likely to win adoption. ${ }^{70}$ The strongest argument against Resolution A's excessive structural change, however, is that such a broad delegation of legislative power to the President is legally questionable and politically dangerous.

68. Resolution $A$ is designed as well to solve one additional, arguably structural, problem: coordination. See RosDs to REForM, supra note 8, at 94-99. This Note does not address that issue, because poor coordination appears to be neither unique nor inherent to agency regulation. The President already has potent tools for coordination. See Bruff, supra note 13 , at 488-97. ABA Resolution B, a proposal that would authorize interagency participation in rulemaking, see note 102 infra, proposes reforms much more relevant to that problem. Resolution A would improve coordination in only two ways: by directing agencies to consider particular issues, the President could reduce policy gaps; and by influencing the outcome of decisions, he could move the government in a consistent direction.

The President is already able to direct executive branch officers to consider particular issues: he may require their written opinion upon subjects relating to their duties, U.S. CoNsr. art. II, $\$ 2$, para. I, and he must see that they execute the laws, $i d$. $\$ 3$. Resolution $A$ would thus add the power to compel only independent agencies to consider particular issues. If the President's informal influence were deemed insufficient for such a task, that aspect of Resolution $A$ might be adopted to improve coordination, but it ought to be uncoupled from the power to direct the outcome of agency decisions. The power to move the government in a given direction is legislative as well as managerial; that is, in directing the outcome of decisions, a coordinator would also be a legislator. The minimal increase in consistency from Resolution $\mathrm{A}$ would therefore exact a high cost by denying Congress its rightful power to set the course of government.

69. The "matching, or mismatching, of regulatory objectives and regulatory means" has been a principal criticism of the regulatory system. Breyer, supra note 2, at 551 . Breyer sets out a "simple axiom for creating and implementing any program [of regulatory reform]: determine one's objectives, examine the alternative methods of obtaining those objectives, and choose the best method for doing so." Id. at $\mathbf{5 5 0 .}$

70. Such a reform would involve a lesser redistribution of political power. See pp. 564-67 supra; Federal. Regulation and Regulatory Reform, supra note 8, at 532-34 (congressional committec report critical of Cutler-Johnson proposal); McGowan, supra note 5 , at $1170-71$ (because regulatory agencies were made independent to limit presidential power, some congressmen see Cutler-Johnson proposal as "putting the fox in charge of the chicken coop"). 


\section{A. The Legal Case for a Tightly Fitted Delegation}

After years of dormancy, the nondelegation doctrine has recently enjoyed a modest revival. ${ }^{71}$ Although the Supreme Court has not struck down a congressional delegation since A.L.A. Schechter Poultry Corp. v. United States, ${ }^{72}$ the doctrine has caused the Court to interpret narrowly statutes that delegate distinctively legislative functions ${ }^{73}$ or that grant standardless discretion in areas touching on fundamental liberties. ${ }^{74}$ Congress itself has shown increased sensitivity to the constitutional validity of its delegations; ${ }^{75}$ even the doctrine's harshest critics concede that Congress is not likely again to enact a delegation as sweeping as that in Schechter. ${ }^{70}$

It is conceded that the Court upholds broad and standardless delegations when they seem to fit a legitimate governmental purpose. ${ }^{77}$ Justifications have depended upon the subject matter and circumstances of each case. Resolution A, however, is devoid of the features that have saved other sweeping delegations. ${ }^{78}$ Under that proposal, presidential discretion would not be limited to certain industries ${ }^{79}$ or to particular means. ${ }^{80}$ The President would be guided by neither ex-

71. See, e.g., Gewirtz, The Courts, Congress, and Executive Policy-Making: Notes on Three Doctrines, 40 LAw \& ConTemp. ProB. 46, 49-65 (1976) (describing and urging increased use of nondelegation doctrine); McGowan, supra note 5, at 1130 (discussing "recent rumblings from the Supreme Court" and others favoring constitutional limits on delegation); Wright, Beyond Discretionary Justice, 81 YALE L.J. 575, $582-87$ (1972) (describing and advocating increased use of nondelegation doctrine).

72. 295 U.S. 495 (1935).

73. See National Cable Television Ass'n v. United States, 415 U.S. 336, 340-42 (1974) (reading challenged statute as delegating power to set fees, not taxes, in order "to avoid constitutional problems").

74. See Kent v. Dulles, 357 U.S. 116, $129-30$ (1958) (denying Secretary power to regulate travel, because such delegation would require standards capable of passing "accepted tests"); cf. Smith v. Goguen, 415 U.S. 566, 575 (1974) (legislative abdication of responsibility for setting clear standards in flag mistreatment law makes arbitrary enforcement possible and denies due process).

75. In response to testimony that the House version of the Reorganization Act of 1977 was an unconstitutional delegation of legislative power, Congress adopted procedures that would virtually assure a vote on all presidential reorganizations. See H.R. REP. No. 105, 95th Cong., 1st Sess. 9-18, reprinted in [1977] U.S. Code Cong. \& AD. NEws 49-57.

76. E.g., K. Davis, Administrative Law Treatise $\$ 3: 8$ (2d ed. 1978).

77. E.g., Yakus v. United States, 321 U.S. 414, 426-27 (1944) ("fair and equitable" standards adequate in wartime price controls); Amalgamated Meat Cutters \& Butcher Workmen v. Connally, 337 F. Supp. 737, 747-58 (D.D.C. 1971) (legislative purpose and "inherent" fairness is standard for wage controls).

78. See note 35 supra (discussing breadth of Resolution A).

79. See Fahey v. Mallonee, 332 U.S. 245, 250 (1947) (standardless delegation upheld in part because it dealt with single type of enterprise); Panama Ref. Co. v. Ryan, 293 U.S. 388, 434-35 (1935) (Cardozo, J., dissenting) (President is "to confine himself to a particular commodity").

80. See, e.g., Amalgamated Meat Cutters \& Butcher Workmen v. Connally, 337 F. 
plicit standards nor a legislative policy, ${ }^{81}$ but could choose freely from among innumerable standards and policies. His power would not be confined to a recognized crisis of limited duration ${ }^{82}$ or to an area of traditional presidential preeminence. ${ }^{83}$ As Mr. Justice Cardozo said of an earlier delegation, Resolution A would give the President a "roving commission to inquire into evils and then, upon discovering them, do anything he pleases." 84

\section{B. The Policies of Nondelegation}

Whether or not a court would hold that Resolution A violates the nondelegation doctrine, Congress should consider the policies that underlie the doctrine before enacting so drastic a reform. With a sweeping grant of power to the President, Resolution A proposes to solve each of the three problems analyzed in Part II: the President is a generalist capable of balancing; his authority could not exceed the broad scope of his competence; elections hold him to account. Yet each of those solutions is constrained by a distinct countervailing nondelegation policy. These three policy constraints limit majoritarian democracy in the name of controlled discretion, separation of powers, and constitutional integrity.

\section{The Danger to Controlled Discretion}

To minimize administrative arbitrariness, Congress must delegate authority with narrow limits and clear standards so that administrators

Supp. 737, 747 (D.D.C. 1971) ("While the subject matter [of delegation] was broad, the technique was relatively confined.")

Resolution A would limit the President to the means of the particular agency he chose to work through. But because a major industry is subject to many regulatory regimes, that limit is trivial.

81. By contrast, in Amalgamated Meat Cutters \& Butcher Workmen v. Connally, 337 F. Supp. 737, 747-58 (D.D.C. 1971), a case challenging presidential authority to impose wage controls, the court searched the legislative history and previous price control legislation to find a policy to guide its review. Resolution $A$ has no policy of its own: the President is simply told to choose among policies of other statutes. Standards may guide the use of those other statutes, but the choice among them remains totally discretionary.

82. Crisis may excuse a delegation as necessary to some compelling purpose. See, e.g., Yakus v. United States, 321 U.S. 414 (1944) (upholding wartime Emergency Price Control Act of 1942); United States v. Yoshida Int'l, Inc., 526 F.2d 560, 573 (C.C.P.A. 1975) (Act delegates power to regulate importation during national emergency).

83. Delegations such as those involving presidential powers in foreign relations may be permitted much broader scope. See United States v. Curtiss-Wright Export Corp., 299 U.S. 304, 319-22 (1936).

84. Panama Ref. Co. v. Ryan, 293 U.S. 388, 435 (1935) (Cardozo, J., dissenting). 
can recognize and courts can enforce proper bounds. ${ }^{85}$ By requiring, moreover, that administrative decisions be reasoned, based on a record, and free from outside pressure, Congress can further inhibit the arbitrary exercise of discretion. ${ }^{86}$

Resolution A, however, would permit the President to import into an agency's rulemaking process the goals and policies of every other agency. ${ }^{87}$ It would thereby broaden the agency's effective discretion and obscure its principal guideline for adopting a regulation; judicial review would in many cases become practically impossible. ${ }^{88}$ In addition, if the President intervened there would be no way to complete the agency's record or to isolate its reasoning. ${ }^{99}$ Resolution A's broadscale balancing would thus endanger the safeguards against arbitrari-

85. See, e.g., Yakus v. United States, 321 U.S. 414, 426 (1944); Cushman, The Constitutional Status of the Independent Regulatory Commissions, 24 CoRnelL L.Q. 13, 32 (1938) (relating invalid delegations to violations of due process); Stewart, supra note 38, at 1675 (intrusions into private liberties must be authorized by legislature and contained by courts within legislative bounds).

86. See Citizens to Preserve Overton Park v. Volpe, 401 U.S. 402, 422 (1971) (Black, J., dissenting in part) (hearings needed to prevent arbitrary action); D.C. Fed'n of Civic Ass'ns v. Volpe, 459 F.2d 123I, 1246 (1971), cert. denied, 405 U.S. 1030 (1972) (Secretary must weigh only those factors Congress intended to make relevant and must not consider pressure by congressman).

87. Resolution A would not, however, permit the President to direct an agency to take an action that exceeded its discretionary authority. Report No. 121, supra note 8, at 23. For example, once the Secretary of the Interior found the snail darter to be an endangered species, the President could not order him to authorize completion of the dam that threatened that fish. Id. But few statutes so clearly delineate an agency's duties or the priorities among agency goals as the Endangered Species Act. See TVA v. Hill, 437 U.S. 153,173 (1978).

88. This problem is illustrated by Pacific Legal Foundation v. DOT, 593 F.2d 1338 (D.C. Cir. 1979). There, the court had to determine whether the Secretary's implementation of a safety standard was "consistent with its statutory mandate, rational, and not arbitrary," id. at 1343, under a statute construed to require that any standard take public reaction into account. Id. at 1345. Though the Secretary's discretion was broad, the court was guided by a central principle: it should determine whether the agency had acted pursuant to Congress's purpose of promoting safety. Id. at 1343. If, under Resolution A, the President were to direct the Secretary to delay or modify the standard on grounds that it was inflationary or energy consuming, such an action would probably be within the Secretary's discretion. But the court would then no longer be able to judge the decision by the congressional purposes of auto safety alone; inflation and energy are also congressional concerns. Thus the President could arbitrarily vitiate the auto safety program, and the court would have lost the central principle for reviewing his action.

89. In Pacific Legal Foundation v. DOT, 593 F.2d 1338 (D.C. Cir. 1979), for example, the agency based its standard on a decade of tests and hearings. Id. at 1340-43. Resolution A would permit the President and his staff to receive oral presentations from interested private persons, unless the agency were prohibited from doing so, with only summaries made; thereafter, oral communications between the White House and the Secretary would remain private. Report No. 121, supra note 8 , at 24 . Therefore if the President later directed a reconsideration, the Secretary's new decision would be heavily influenced by unrebutted, nonpublic arguments from one with the ultimate power to modify or reverse his action. 
ness now provided by statutory specification of the scope and process of agency discretion. ${ }^{90}$

\section{The Danger to Separation of Powers}

To protect against excessive concentration of power in one organ of government, Congress must limit the delegation of legislative authority to the President. ${ }^{91}$ The integration of binding legislative, executive, and judicial authority in each of the many agencies does not violate that policy, for agencies possess limited scope and can partially check each other. ${ }^{92}$ But Resolution A proposes a coordination and control of agency authority and thus would create a concentration of power and a danger to the separation of powers that cannot exist so long as the system is fragmented. ${ }^{93}$

\section{The Danger to Constitutional Integrity}

The written guarantees against infringement of individual rights and excessive concentration of power would be worthless if temporary majorities indulged themselves in altering fundamental constitutional arrangements through ordinary legislative channels. ${ }^{94}$ Though the President is deeply involved in lawmaking, the Constitution establishes a unique institutional competence for the legislature: to represent and

90. To mitigate the threat to due process arising from the broad discretion that agencies currently possess, they have been urged to make greater use of rulemaking for policy development. See Bell Tel. Co. of Pa. v. FCC, 503 F.2d 1250, 1265 (3d Cir. 1974), cert. denied, 422 U.S. 1026 (1975); K. Davis, Discretionary Justice 65-66 (1969). Resolution A would likely cause agencies to revert to policymaking through adjudication in order to avoid presidential interference. See Robinson, supra note 20, at 210 n.95; cf. Reich, Politicizing the Fourth Branch, 229 ThE NATION 193, 210-12 (1979) (presidential and legislative review would weaken due process).

91. Separation of powers has two distinct emphases: one is a principle against encroachments, protecting the integrity of the branches; the other is a principle against concentration, protecting the people from tyranny. See McGowan, supra note 5, at 1152. The first of these has been widely discredited as unworkable. See, e.g., Freedman, supra note 62, at 1049-51. The Constitution describes a government of shared, ill-defined, and not wholly separable powers. The principle against excessive concentration of power, however, remains vital. See Gewirtz, supra note 71, at 46-49.

92. See, e.g., TVA v. Hill, 437 U.S. 153 (1978) (Attorney General arguing for TVA against position of Secretary of Interior); FTC v. Ruberoid Co., 343 U.S. 470, 483 (1952) (Jackson, J., dissenting) (noting legal battles between independent and executive agencies).

93. See Coleman Dissent, supra note 33, at 2. The price of this fragmentation is some loss of efficiency and coordination, however, and some friction in the wheels of government. But, as Justice Brandeis said, "[ $[t]$ he doctrine of the separation of powers was adopted ... not to promote efficiency but to preclude the exercise of arbitrary power." Myers v. United States, 272 U.S. 52, 293 (1926) (Brandeis, J., dissenting).

94. See S. Barber, The Constitution and the Delegation of Congressional Power 37 (1975) (by the nature of a constitution, fundamental functions of different branches cannot be changed). 
balance conflicting interests, and thus to choose among competing policy alternatives ${ }^{95}$ To abdicate that duty and hence to rearrange the fundamental allocation of governmental functions would undermine the legitimacy that rests upon a stable constitutional structure.

Resolution A seeks to choose a balancing authority who is directly accountable to the voters rather than to the legislature.96 Because Resolution A would have Congress delegate its task of representing and balancing interests-and thereby its duty to be accountable-the proposal approaches a recommendation for legislative abdication. The President is thought to be the ideal balancer, not because he can best interpret congressional goals, but because, as a nationally elected politician, he articulates the nation's goals. Accountability would thus be gained by circumventing the congressional process of sifting divergent interests. Resolution A would thereby deprive Congress of its essential constitutional function. ${ }^{97}$

Just as the Court has upheld broad and standardless delegation when it seemed to fit a legitimate purpose, ${ }^{98}$ it may be argued that Resolution $A$ is necessary to achieve regulatory balance. To demonstrate that Resolution A is unnecessary, however, Part IV outlines an alternative proposal to achieve regulatory balance by far less drastic means.

\section{The Board of Regulatory Appeals: A Fitting Alternative}

In its attempt to balance conflicting regulatory goals, Resolution A abandons the checks normally imposed upon the delegation of congressional power. By contrast, the proposal set forth in this Note is designed to harness the regulatory system's "inevitable friction." ${ }^{\text {90 }}$ Both

95. See id. at 38 (Congress's "essential act" is deciding between conflicting proposals presented by clashing interests); Freedman, Delegation of Power and Institutional Competence, 43 U. CHI. L. REv. 307, 328 (1976) (legislative role is making basic policy choices).

96. See Cutler \& Johnson, supra note 8 , at 1411 .

97. By shifting lawmaking authority to the President, Resolution A would not only defeat the constitutional arrangement of powers, but would also make possible decisions of even lower consensus: for the period during which Resolution $A$ was in effect, presidential power could withstand the opposition of virtually two-thirds of both houses of Congress and still act affirmatively to implement regulations. Until Congress could override his veto, or until the next presidential election, it could not withdraw his power.

98. See, e.g., Yakus v. United States, 321 U.S. 414, 427 (1944). An otherwise improper delegation may be permitted when necessary to achieve a legitimate purpose. But the delegation should always be measured by legislative need. If a "more restrictive" delegation can be found to accomplish the same goal, then an unlimited or standardless delegation should not be permitted. See Clean Air Constituency v. California State Air Resources Bd., 11 Cal. 3d 801, 818, 523 P.2d 617, 627, 114 Cal. Rptr. 577, 587 (1974) (standard must not give agency more discretion than necessary for legislative purpose).

99. Myers v. United States, 272 U.S. 52, 293 (1926) (Brandeis, J., dissenting) (purpose of separation of powers doctrine was "not to avoid friction, but, by means of the inevitable friction incident to the distribution of the governmental powers among three departments, to save the people from autocracy"). 
proposals recognize a structural need to delegate balancing authority. They differ with respect to the identity of the balancer and the nature of his authority. The approach of this Note, however, would achieve the desired ends without raising the political and constitutional difficulties inherent in Resolution A.

\section{A. Meeting the Need for Balance}

The balancer cannot and need not consider the effects of every regulation upon every goal. ${ }^{100}$ Narrow interests and perspectives are more efficiently balanced by permitting competition among them. ${ }^{101}$ To achieve this competition, agency administrators should be given standing to appeal the rules of other agencies that affect their mandated goals. ${ }^{102}$ Important value conflicts would thus be raised by the most interested and authoritative spokesmen. ${ }^{103}$

This Note proposes creation of an independent Board of Regulatory Appeals to hear those conflicts. ${ }^{104}$ Curing overregulation with another agency would not be without irony, but the new Board would be constituted more like a court than like a regulatory agency. ${ }^{105}$ Instead of experts, it would consist of generalists capable of weighing evidence over a wide range of technical and nontechnical issues. Because balancing regulatory goals would be its only job, the Board would be

100. The scheme of Resolution A admittedly would require the collective efforts of the President's staff to sift, sort, and summarize regulations before the President could deal with even a few. To conserve scarce time, the President would likely intervene in only the three or four most significant cases each year. Report No. 121, supra note 8, at 27.

101. A decentralized system would harness the incentive of interagency competition to locate conflicting regulations and would exploit the natural division of administrative labor to argue the issues. Resolution $A$ would be less efficient because a centralized staff would have to review thousands of regulations to find a handful of conflicts.

102. To facilitate early resolution of conflicts and adequate development of the issues, this Note also proposes that agencies be authorized and encouraged to participate on the record in the early stages of other agencies' rulemaking proceedings. Participation might take the form of submissions and argument during the comment period, see, e.g., S. 382, 96th Cong., Ist Sess., 125 Cong. REc. 1272 (daily ed. Feb. 7, 1979) (authorizing FTC to comment on competition effect of proposed rules), or interagency review and regulatory analyses, see ABA Resolution B, reprinted in Report No. 121, supra note 8, at 2, 28-33; Coleman Dissent, supra note 33, at 6-8. Such participation would not affect the final authority to issue rules, which would remain with the agency or, after appeal, with the Board of Regulatory Ảppeals proposed in this Note.

103. To ensure that societal values are adequately represented by such a system, Congress might establish ombudsmen or a public advocate agency, see Lazarus \& Onek, supra note 3 , at 1103-05, to appeal on behalf of goals that would otherwise lack a governmental spokesman.

104. An important advantage of the system is that it would enable Congress to confine agencies within narrower limits. See p. 567 supra. Narrowing the agency focus would help to achieve the advantages of specialization and to alleviate the problems of control and arbitrariness. See pp. 575-77 supra.

105. The Board might be given a small staff to help evaluate issues as they are appealed, but it would have no investigative or enforcement duties. 
better able to consider its choices carefully and to analyze publicly the predicted effects of alternate rules. ${ }^{106}$ Its broad mission might give it greater freedom from special interests and from the biases of specialized agencies. $^{10 \tau}$ Like a court, the Board would tend to value rational social choice. ${ }^{108}$

The Board would probably be better suited than a busy President to determine balances. Moreover, its chief contribution would be not its decisions as such, but rather the incentive it would create for agencies to check and balance each other. ${ }^{109}$

\section{B. Limiting Necessary Authority}

Resolution A would give the President in effect the power to legislate on his own initiative, even though balancing requires only the authority to resolve critical conflicts as they arise. ${ }^{110}$ The Board could exercise the latter authority as well as the President but, unlike the President, could not veto legislative reversals of its decisions or endanger the separation of powers.

The Board would have authority to act only on appeal, not on its own initiative. A rule could be challenged only after it was promul-

106. Though the Board would be concerned with broad policies, in order to evaluate conflicts it must apply those policies with a more detailed understanding of regulatory impact and issues than Congress has time to develop. By making its reasoning public, the Board would have greater incentive to consider all relevant factors. An appointed Board might also be less likely than Congress or the President to be swayed by momentary political needs.

107. Some commentators have proposed creation of an "Administrative Court," see, e.g., Ash Council Report, supra note 7, at 53-55, to engage in individual adjudications, see Nathanson, The Administrative Court Proposal, 57 VA. L. REv. 996 (1971). Professor Nathanson's study concluded that judicial or quasi-judicial institutions whose jurisdiction is "generalized in its impact on society" are better able to avoid suspicion of bias or domination by special interests. Id. at 1012; cf. Robinson, supra note 17, at 956 (agencies with broad constituencies less subject to special interests).

108. The Board would lack a special-interest constituency, and all contact with interested parties would be open and on the record. It is reasonable to assume, therefore, that a principal source of the Board's legitimacy would derive from the persuasiveness of its opinions. Its independence would permit it, moreover, to base its choice upon the collective preference of the Congress rather than upon a negotiated and logrolled accommodation by numerous factions.

109. It would be difficult to prevent the President from influencing executive officers in their decisions about whether to appeal, and by controlling appeals, he could weaken the Board's effectiveness. He could not control independent agency appeals of executivebranch decisions, however, nor could he force the Board to hear appeals it found to be insignificant.

110. The authority of agencies to make binding decisions within their own fields of competence is an important feature of the regulatory system and should not be disturbed. The problem of authority arises when an agency's action affects values outside its competence, and the best indication that that has occurred is the protest of another agency. The power to resolve that conflict is sufficient for purposes of balancing; the balancer need not be given the power to initiate a veto or to enact affirmative regulations. 
gated, ${ }^{111}$ and then only if the Board found that a critical regulation was involved and that statutorily mandated policies of the petitioning agency were affected. ${ }^{112}$ Appeal would be expedited, and only agency representatives could appear or comment by right. ${ }^{113}$ The bulk of the work would be done by the parties-that is, agency administrators, the President, and their staffs ${ }^{114}$-and all argument would be on the public record. ${ }^{115}$

After hearing the appeal, the Board would issue findings and could order an agency to reconsider, and ultimately to modify or reverse, its decision. In ordering modifications, the Board could choose among the policy options of those agencies before it, but could compel agencies to undertake only the types of action normally falling within their statutory mandate. ${ }^{116}$ Until the agency had completed its process of

111. Before promulgation, however, the appealing agency would presumably have participated in the rulemaking through comments or interagency review. See note 102 supra. Realization that the opposing agency might appeal to the Board would encourage the issuing agency to compromise and to consider balancing.

112. The Board would need some method of limiting the number of appeals. The required findings would enable it to control its docket.

113. Members of Congress might also be given standing to appeal in order that constituency interests could be heard. Such a proposal might cause the process to break down from overuse, however. Although foreclosing public participation might be objectionable, the appeals process must be limited or a balance could never be imposed. The Board is intended to facilitate balance among existing legislative goals; the promotion of currently unrepresented interests and goals may be left to other reforms. As a practical matter, most interests can find an advocate within the regulatory system, especially if the President and a public advocate agency have standing. See note 103 supra. The Board might also consolidate all appeals or permit interested persons to comment if wider participation appeared necessary for balance.

114. This system would thus tap the agencies' technical expertise. Moreover, the burden upon the appealing and responding agencies would be diminished to the extent that they had already argued the issues in the prior rulemaking.

115. Requiring that all communications with the Board be on the record could minimize the ex parte contact problems posed by Resolution $\mathrm{A}$ and the legislative veto. See Reich, supra note 90, at 210-12. Congress and the President could not and should not be cut off from their constituents; keeping a record of all contacts with private persons would not restore the appearance of fairness so long as the President or a congressman could privately influence an agency by threatening to invoke Resolution $A$ or a legislative veto. But keeping the record before the Board public would be relatively easy, for the Board would perform no political (i.e., electoral) functions.

116. The Board's order would be the functional equivalent of a legislative act overturning a rule or directing the agency to give weight to a particular factor in formulating its rule. To the extent that the agency's statute did not specify that the factor in question could be considered (e.g., the cost factor in EPA's setting of air quality standards, see note 46 supra), the Board would indeed be directing the agency to exceed its statutory mandate. But all such extentions of statutory bounds would be limited to the rule in question and, in any case, would not change the type of action the agency was authorized to take. Moreover, the factor to be weighed would have to be supplied from the statutory mandate of the appealing agency. If Congress had indicated its priorities from among those factors, the Board would not have discretion to ignore the congressional preference. 
modification, the challenged rule would remain in force as initially promulgated. ${ }^{117}$

As described, the Board would function somewhat like a court. Within the broad outline of competing statutory goals, however, it would be making a policy, rather than a legal, decision. A court is limited to keeping an agency within its statutory mandate and ensuring that the agency's decisions are not arbitrary. The Board, on the other hand, would be authorized to strike down actions that were legally unassailable. If the legislature had statutorily established its priorities among several regulatory goals, the Board would be legally bound to respect that preference. ${ }^{118}$ But if statutory goals conflicted and Congress had expressed no formal preference among them, the Board could overrule an agency's valid rule without needing to obtain new legislation.

\section{Accounting to Congress}

Resolution A would vest balancing authority in the President because it presumes that a nationally elected official is best able to assure consistency between regulatory compromises and societal values. ${ }^{110}$ That function, however, is essentially a legislative one. ${ }^{120}$ The degree of presidential accountability and responsiveness, moreover, is easily overstated. $^{121}$ The President must account to the voters for his performance at most only once. The importance of any particular action to his reelection is therefore quite small. ${ }^{122}$ The potential for mischief

117. The Board might be given authority, in exceptional circumstances, to issue a temporary restraining order to prevent a rule from going into effect. Where the Board ordered a reconsideration, the agency would adhere to its own rulemaking procedures. As in Resolution $A$, the Board could reverse or modify only after ordering reconsideration. Where reversal or modification was ordered, the agency would be given a fixed period of time in which to act and would not be required to permit public participation.

118. See note 50 supra.

119. Report No. 121, supra note 8 , at 11; see pp. 577-78 supra.

120. See United States v. Robel, 389 U.S. 258, 276 (1967) (Brennan, J., concurring) ("Formulation of policy is a legislature's primary responsibility, entrusted to it by the electorate . . ."); Freedman, supra note 95, at 328 (describing legislature's institutional competence to make basic policy choices).

121. The President quickly becomes insulated from the day-to-day political feedback upon which he built his earlier career and operates in a world of unreality. See G. Reedy, The Twilight of the Presidency passim (1970). Some argue that he is, however, responsive to special interests, and that independent agencies, by contrast, can sometimes better resist special-interest pressures. See Lazarus \& Onek, supra note 3, at 1082-84.

122. The President knows well that his popularity will drop throughout each term, see T. Cronin, supra note 15 , at 110-11, that few voters will know or care about any given issue, see Converse, The Nature of Belief Systems in Mass Publics, in Ideology and DisCONTENT 206, 213-19 (D. Apter ed. 1964), but that he will probably be able to use his office to sufficient advantage to get himself reelected, see E. TuFre, Political Control of the EcoNomy 135 (1978). If he is reelected, the President will spend four years with no need to continue pleasing the voters. 
from Resolution A's grant of power, on the other hand, is enormous. ${ }^{123}$ Congress is the proper institution to serve as the source of balancing authority. Though the President is more representative of the nation than a single-mission agency or a single member of Congress, he is not more representative than Congress when it is able to act as a body. ${ }^{124}$

The Board would not presume to represent the people directly, but would instead be a delegate of Congress. ${ }^{125}$ It would evaluate predicted effects of agency regulations, weigh competing legislative purposes, and base its choice upon its estimate of the hypothetical balance of preferences in Congress as a whole. The accuracy of its estimate would be less important than its congressional orientation. Because the Board would make only these decisions, it would assume greater responsibility for their consequences. ${ }^{126}$ With less power and less opportunity to abuse that power, the Board could not escape firm legislative control. ${ }^{127}$

The key to making the Board fully accountable would be a joint congressional oversight committee with sufficient power and representativeness to speak for Congress as a whole. ${ }^{128}$ Such a committee could guide the Board as to general congressional priorities and ex-

123. See pp. 565.67 supra.

124. See Gewirtz, supra note 71, at 47; cf. Karpatkin Dissent, supra note 33, at 2 (legislature more attuned to wishes of electorate).

125. Members of the Board would be appointed by the President for a fixed term and removable only for cause. A sunset provision would create a continuing need to renew its mandate. In the Board's organic legislation, Congress would include broad guidelines defining its mission and, where possible, setting its priorities. Congress would also instruct it to take account of expressions of congressional will. See 2 STUDY on Federal RegulaTion, supra note 1 , at 9 (instructions to consider congressional resolutions are written into some statutes). The Board's actions would be subject to judicial review to assure conformity with its own statutory procedures and to enforce limited adherence to the agencies' statutory powers. See note 116 supra. If priorities among regulatory goals had been expressed in legislation, the Board's balancing decision would be reviewable for conformity with those priorities; the Board's policy choices would otherwise be conclusive. These devices would serve the practical and constitutional requirements for limiting the delegation and ensuring its adherence to the legislative will.

126. The Board's decisions would be highly visible to those who held it accountable. On the other hand, it is unlikely that a President's reelection would hinge to any great extent upon his regulatory interventions.

127. Whereas a decision by the President pursuant to Resolution A would affect his total relationship with Congress, the consequences of a Board decision would be more confined. The Board would typically be choosing between two congressionally established agencies on a single rule, and a "wrong" choice would burden Congress with a problem no greater than that now imposed by unbalanced agency decisions. The very existence of the Board, however, would make the agencies conscious of values outside their domain. This change in the regulatory system would be more important than any particular Board decision.

128. The Joint Committee on the Budget has been one of the more successful congressional reforms of recent years. Aided by a professional staff, the congressional budgeters set priorities, make difficult decisions, and get their compromises enacted despite powerful committees. But cf. Cutler \& Johnson, supra note 8, at 1412 n.58 (analogous "Joint Committee on Economic Regulation" unlikely). 
plain the Board's position to Congress. Because it would not specialize in a particular group of industries or problems, the committee would incline less toward parochialism. Experience in the actual problems of the Board would heighten the committee's sense of responsibility for the success of the process. Finally, having such a Board and oversight committee might force legislators to face priority-setting problems and to take their duties as national policymakers more seriously. ${ }^{129}$

The need for accountability to Congress is the principal reason that a court could not perform the functions of the Board. With life tenure and an independent, constitutional basis of power, courts are not sufficiently responsive to make fundamental policy choices in the absense of legislative guidance. ${ }^{130}$ Any attempt to hold the judiciary to account through congressional oversight would meet serious separation-ofpowers objections. As an independent agency, on the other hand, the Board would reestablish congressional control over other independent agencies within an institutional form that has long been held constitutional. ${ }^{131}$

\section{Conclusion}

The proposal of this Note demonstrates that a mechanism for ensuring regulatory balance can be achieved without the dangerously broad delegation of Resolution A. The scheme envisions little shift in the balance of power between Congress and the President, and so should encounter less opposition than Resolution A. Both actors would yield some power: Congress's independent agencies would be less independent, insofar as other agencies could challenge their decisions, and the President would find his departments answerable to a congressionally established institution. But both would gain as well: the President could appeal on broad policy grounds against rules issuing from a

129. Commentators have noted the strong positive relationship between a sense of responsibility and working experience with accountable power. See, e.g., A. Bickel, THE LeAst DANGerous Branch 21-22 (1960) (judicial review diminishes congressional responsibility for the constitutionality of legislation); McGowan, supra note 5, at 1148 (discussing argument that congressional power over regulation encourages responsibility). In contrast, Congress's distant observation of presidential intervention under Resolution $A$ would only lead to nonconstructive criticism and loss of responsibility.

130. The duration of the Board under the sunset provision, the length of members' tenure, and the timing of their appointments would all affect the Board's responsiveness to both Congress and the President. The determination of these issues is best left as a point of negotiation in whatever compromise would lead to the Board's establishment.

131. See Humphrey's Ex'r v. United States, 295 U.S. 602, 628-29 (1935) (Congress has authority to create independent agencies); cf. FTC v. Ruberoid Co., 343 U.S. 470, 485-89 (1952) (Jackson, J., dissenting) (rationale for agency independence is to complete legislative policy choice). 
narrow statutory mandate, while Congress might achieve firmer control over the direction of regulatory policy through oversight and resolutions. The need for periodic renewal of the Board would assure that balances were responsive to both presidential and congressional concerns. ${ }^{132}$

Resolution A would weaken Congress's sense of responsibility by reducing its need to control its delegates. In contrast, the Board of Regulatory Appeals would be more effective and less dangerous because it would increase congressional responsibility rather than presidential power.

132. The original Cutler-Johnson proposal, which included a legislative veto, see notes 8 \& 26 supra, was also a compromise. That proposal would increase presidential and congressional power at the expense of the agencies by impairing their independence and their ability to carry out a consistent program. See McGowan, supra note 5, at 1170. It would facilitate special-interest interference in regulatory policy through both the President and Congress without any real improvement in balancing. It would also overlay the regulatory bureaucracy with a parallel bureaucracy in the White House-a group of staff aides whose political future would be affected by the interventions they could successfully bring to the President's attention. The compromise of this Note, by contrast, would provide regulators with ample incentive to intervene in another agency's actions, but only if their own area of authority were truly violated. 